\title{
Nuclear Inclusions in Oculopharyngeal Muscular Dystrophy in Quebec
}

\author{
Jean-Pierre Bouchard, François Gagné, Fernando M. S. Tomé, Denis Brunet,
}

\begin{abstract}
Seven French-Canadian cases of clearcut oculopharyngeal muscular dystrophy (OPMD) had their muscle studied for the presence of intranuclear inclusions, and they were all positive. Inclusions of both "mature" and "immature" types were seen in our material. The presence of such intranuclear structures should be added to the criteria of the clinical picture and the family history for diagnosis of a case and inclusion of a family in further genetic studies. Reverse genetic studies of large families and biochemical studies of these intranuclear structures may help to understand the pathogenesis of this common disease in Quebec.

RÉSUMÉ: Inclusions nucléaires dans la Dystrophie Musculaire Oculopharyngée au Québec Nous avons étudié sept cas canadiens-français de dystrophie oculopharyngée classique et nous avons retrouvé dans chaque cas des inclusions intranucléaires dans les muscles striés. Ces inclusions étaient le plus souvent de forme typique, mais nous avons parfois noté dans les mêmes muscles des inclusions de forme "immature". Il nous paraît maintenant nécessaire d'ajouter la présence de ces structures intranucléaires aux critères habituels du tableau clinique et de l'histoire familiale pour confirmer le diagnostic d'un cas isolé ou l'inclusion d'une famille dans une étude génétique. Les études de génétique inverse sur de grandes familles affectées et l'analyse biochimique de ces inclusions intranucléaires devrait nous aider à mieux comprendre la pathogénèse de cette maladie fréquente au Québec.
\end{abstract}

Can. J. Neurol. Sci. 1989; 16:446-450

Oculopharyngeal muscular dystrophy was fully described for the first time by E.W. Taylor ${ }^{1}$ in 1915 in a family originating from French Canada. Victor et $\mathrm{al}^{2}$ coined the name in 1962 when reporting a Jewish family that immigrated to the U.S.A. from Central Europe. In 1966 A. Barbeau was able to link most of the cases already described in North America ${ }^{(1,3-8)}$, and a number of other families in Quebec, to a common ancestor couple that immigrated from France in $1634 .{ }^{9}$ He then confirmed the clinical picture ${ }^{10}$ by studying more than 50 cases in Quebec. $\mathrm{He}$ also started some genetic studies with blood markers $11-12$ and

\begin{tabular}{|c|c|c|c|c|c|c|}
\hline Case & Age & Ptosis & Dysphagia & CK & Other features & Muscle(s) \\
\hline I(YC) & 71 & $\mathrm{R}>\mathrm{L}$ & $\begin{array}{l}\text { severe weight loss } \\
\text { myotomy (1987) }\end{array}$ & & hoarse voice & $\begin{array}{l}\text { Cricopharyngeus } \\
\text { Sternocleidomastoid }\end{array}$ \\
\hline $2(\mathrm{RL})$ & 66 & corrected & none (?) & 418 & $\begin{array}{l}\text { proximal weakness } \\
\text { U.L. < L.L. }\end{array}$ & Deltoid \\
\hline $3(\mathrm{AT})$ & 63 & bilateral & moderate & 360 & $\begin{array}{l}\text { proximal weakness } \\
\text { ophthalmoparesis }\end{array}$ & $\begin{array}{l}\text { Cricopharyngeus } \\
\text { Deltoid }\end{array}$ \\
\hline $4(\mathrm{LT})$ & 79 & bilateral & $\begin{array}{l}\text { severe pneumonias } \\
\text { myotomy (1981) }\end{array}$ & 52 & $\begin{array}{l}\text { nasal voice } \\
\text { death } 1987\end{array}$ & $\begin{array}{l}\text { Deltoid } \\
\text { (autopsy) }\end{array}$ \\
\hline $5(\mathrm{FQ})$ & 56 & $\mathrm{R}<\mathrm{L}$ & mild & 110 & ALS, death 1988 & Deltoid \\
\hline $6(\mathrm{AB})$ & 83 & bilateral & $\begin{array}{l}\text { moderate } \\
\text { myotomy -----> }\end{array}$ & 64 & $\begin{array}{l}\text { Parkinson's } \\
\text { diabetes, cataracts } \\
\text { death } 1988\end{array}$ & $\begin{array}{l}\text { Deltoid } \\
\text { (autopsy) }\end{array}$ \\
\hline $7(\mathrm{MS})$ & 69 & $\begin{array}{l}\mathrm{R}<\mathrm{L} \\
\text { corrected } \\
1976\end{array}$ & $\begin{array}{l}\text { mild in } 1976 \\
\text { mild in } 1988\end{array}$ & 1520 & $\begin{array}{l}\text { proximal weakness } \\
\text { ophthalmoplegia } \\
\text { cataracts }\end{array}$ & Deltoid \\
\hline
\end{tabular}

De l'Hôpital de l'Enfant-Jésus, Université Laval, Québec, (J.-P.B., F.G., D.B.) et INSERM, Unité 153, Paris (F.M.S.T.)

Presented in part at the XXIIIrd Canadian Congress of Neurological Sciences, Quebec City, Canada, June 1988, et au IIIème Colloque National sur les Maladies Neuromusculaires, Bordeaux-Lac, France, juin 1988.

Reprint requests to: Dr. J.-P. Bouchard, Département des Sciences Neurologiques, Hôpital de l'Enfant-Jésus, 1401 18è rue, Québec, P.Q., Canada GIJ IZ4. 


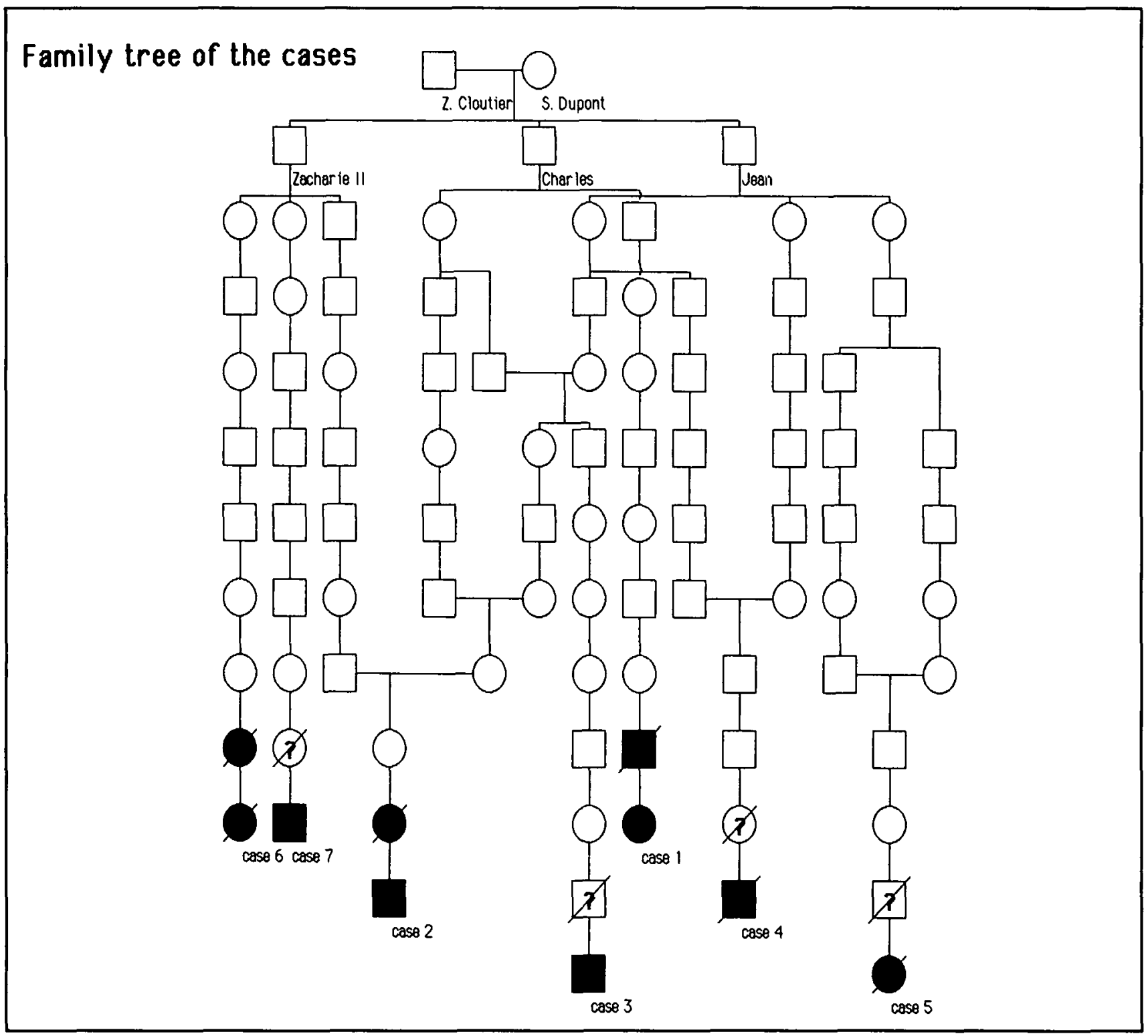

Figure 1 - Family tree of the seven cases, linking them all to a common ancestor couple that immigrated to Québec from France in l634.

dermatoglyphs, and also looked for an association with Daltonism. He left these studies, however, to come back to research on L-DOPA treatment of Parkinson disease. Although Barbeau's contribution was greater and more sustained in some other fields (Parkinson disease, Huntington's chorea, Friedreich's ataxia), in Quebec today oculopharyngeal muscular dystrophy (OPMD) is often called "la maladie de Barbeau".

\section{Material AND MethodS}

From our pool of OPMD patients, seven yielded muscular tissue specimens for morphological study in 1987-1988. The main clinical features and procedural data are given in Table 1. All patients were French-Canadians living in Quebec and presenting with a familial history of the disease. They were not known to be related to the other cases, but all could be linked to the ancestor couple previously described by Barbeau ${ }^{9}$ as shown in Figure 1.

Samples of muscle were quick-frozen in isopentane cooled to $-160^{\circ} \mathrm{C}$ in liquid nitrogen, cryostat-sectioned and submitted to histological and histoenzymologic examination.

Electron microscopy (EM) fragments were fixed in cold $0.1 \%$ glutaraldehyde and $2.0 \%$ formaldehyde in $1.12 \mathrm{M}$ sodium cacodylate- $\mathrm{HCl}$ buffer at $\mathrm{pH} 7.3$ for a minimum duration of 2 hours, rinsed in buffer, post-fixed in osmic acid $2 \%$ in cacodylate buffer, treated in saturated uranyl acetate for one hour, dehydrated in graded alcohols and embedded in epoxy resin (Epon).

Semithin sections were stained by paraphenylenediamine and/or toluidine blue and examined under light microscope. Thin sections were stained by lead nitrate-sodium citrate and studied by electron microscopy. 


\section{Results}

In seven specimens (six from deltoid and one from the sternocleidomastoid muscle), the general architecture of muscular tissue was well preserved and pathological changes were slight to moderate. In every case we were able to identify by EM the specific tubulofilamentous intranuclear structures described by Tomé and Fardeau. 13-17 These appear as accumulations of short $(0.1 \mu \mathrm{m})$, rather straight, unbranched $8.5 \mathrm{~nm}$ wide filaments, irregularly oriented but often disposed in roughly parallel pseudopalissading groups (Figure 2). These inclusions are not membrane-bound and their volume is quite variable. At their periphery or in the very small and probably incipient forms, they appear to mingle with the chromatin granules. Some of these may remain scattered or grouped within the inclusion itself.

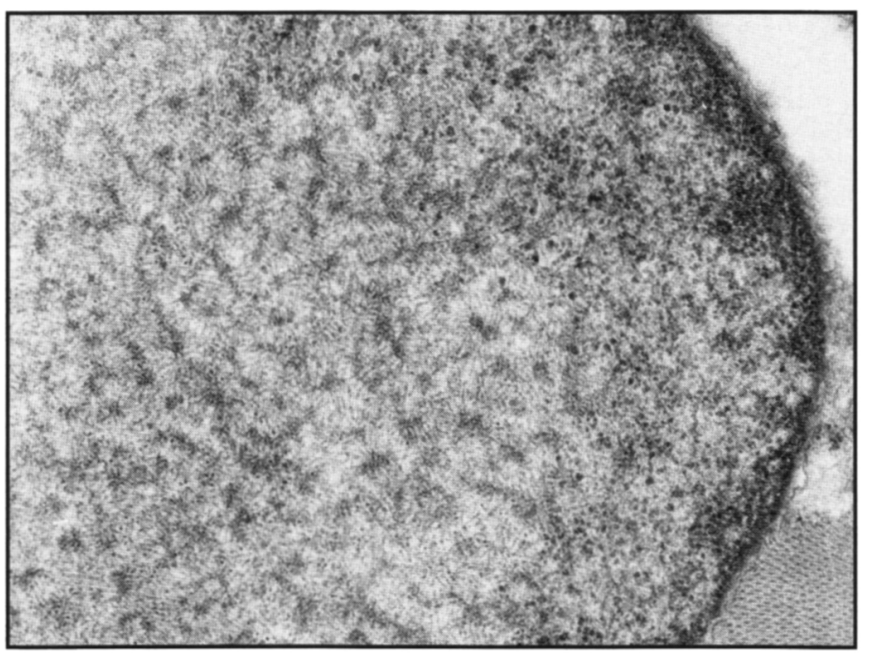

Figure 2 - Portion of a myonucleus exhibiting an extensive deposit of filamentous material, shown as short, unbranched, nearly rectilinear structures, often clustered or in pseudopallisades. The inclusion is not membrane-bound, and is imperfectly demarcated from the nuclear chromatin (Case 2). EM $\times 50,000$.
Their position is central or paracentral in the affected nuclei. At high magnification, transverse sections of the filaments reveal their tubular nature, the empty central space measuring $3 \mathrm{~nm}$ in diameter (Figure 3). A longitudinal periodicity of $7.0-7.5 \mathrm{~nm}$ is sometimes seen. In some nuclei the tubular structure and the palissade arrangement are not seen, but there are inclusions of a looser filamentous material, such as found in innervated cultured muscle fibres from patients with OPMD $18 \mathrm{a}, \mathrm{b}$ and thought to be "immature" formations. So far, only the tubulofilamentous inclusions are considered for the diagnosis of OPMD.

The inclusions are clearly identified in only 3 to $6.5 \%$ of the muscle nuclei, according to Tomé, but they may exist in all myonuclei. ${ }^{19}$ Their identification can be a long and tedious task. In toluidine-blue stained semi-thin sections, they appear as palestaining nuclear areas, 15,19 as shown in Figure 4 . These can guide in the selection of fields to be submitted to EM examination. Clearly involved nuclei are often rather plump with a conspicuous nucleolus.

Another morphological alteration to be looked for in OPMD muscle is the "rimmed vacuole". The presence of such lesions was first emphasized in OPMD by Dubowitz and Brooke. ${ }^{20}$ They are found in frozen sections as variably shaped clear spaces, central or peripheral in the fibre, surrounded by a poorly defined rim of basophilic material with $H \& E$ stain, but red with modified trichrome. Ultrastructurally these are large autophagic vacuoles occupied by numerous dense concentric lamellar structures, vacuolar spaces, and bodies of variable shape and electron density (Figure 5). These lesions were numerous in cases 6 and 7 , not so conspicuous in cases 1,2 and 5, and only a small number were found in the two remaining cases.

The rimmed vacuoles are not specific to OPMD but constitute one of its usual hallmarks. Other constant findings are variation in muscle fibre size, without obvious hypertrophy, and occasional central nuclei. Subsarcolemmal grouping of mitochondria and "ragged red" fibres are rarely seen. Case 5 had concomitant amyotrophic lateral sclerosis and consequently

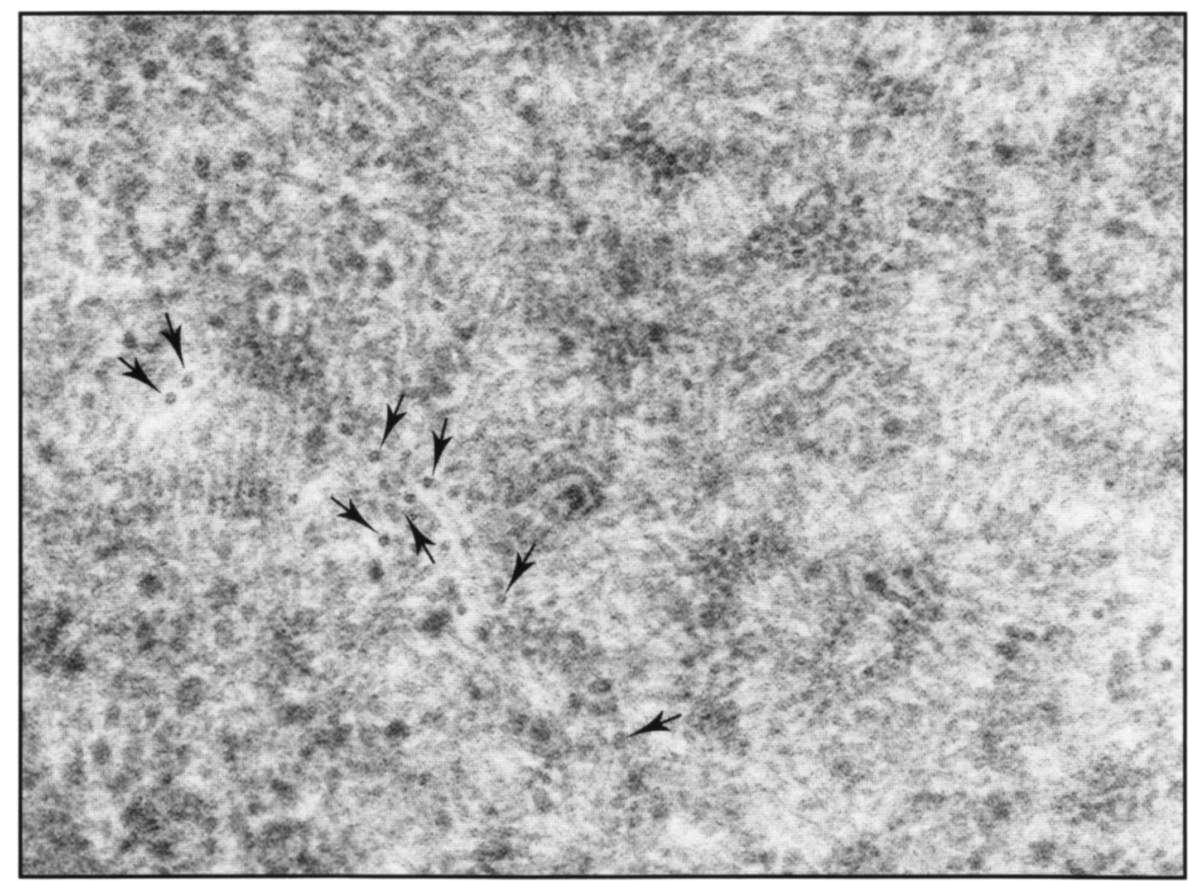

Figure 3 - Higher magnification reveals the tubular nature of the inclusion material, as shown in cross-section (arrows) (case 3). $E M \times 136,000$. 


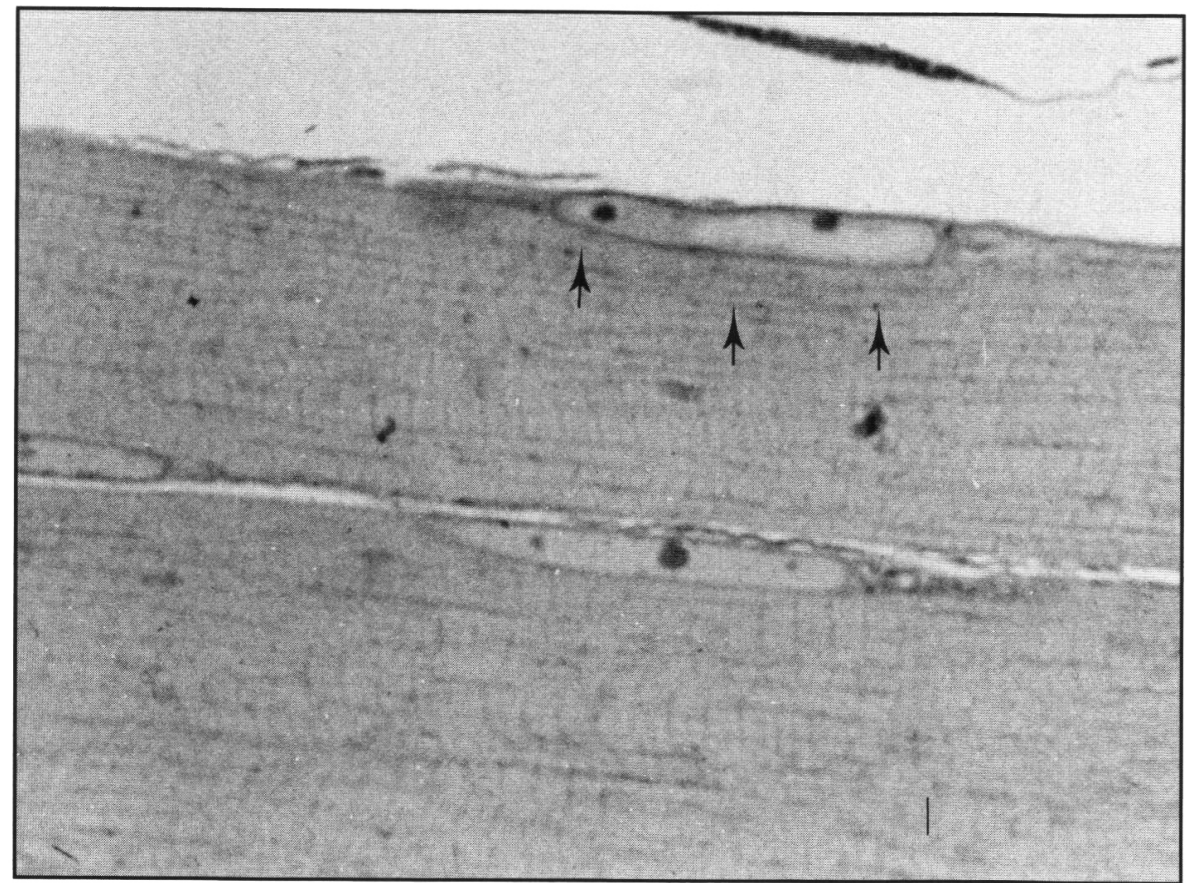

denervation muscular atrophy dominated the histologic picture.

In addition two inferior pharyngeal constrictor samples were obtained from cases 1 and 3. Morphological changes were much more impressive than in the limb muscles. Muscle atrophy was severe as shown by marked muscle fibre loss and extensive fibrous and fatty replacement. A large sub-sarcolemmal mitochondrial pool was often seen in remaining fibres. We failed to demonstrate the specific inclusions in the nuclei of these two samples. Although hard to find in severely atrophic constrictor muscles, the presence of these inclusions has been reported by others ${ }^{14}$ and we found some in a few other cases.
Figure 4-The inclusions are seen as palestaining intramuclear areas (arrow's) in sections embedded in epoxy resin and stained with toluidine blue (Case 5). EM $\times 1,000$.

\section{Discussion}

The tubulofilamentous intranclear inclusions found in OPMD are morphologically distinct from other filamentous structures observed in muscular tissue. ${ }^{15,16}$ So far they are the only ultrastructural muscle change that is totally specific to one primary muscle disease. They have now been found in every unquestionable case of OPMD in many countries in Europe ${ }^{14}$ and also in subjects of Spanish origin in North and South America. ${ }^{17}$ Reports of their occurrence in cases of FrenchCanadian extraction $21-23$ are still very few and brief.

Figure 5-Ultrastructural morphology of a rimmed vacuole: saggittal section of a muscle fibre featuring a large central sarcoplas. mic deposit of pleomorphic material, partly granular or vacuolar, with prominent concentric multilamellar structures. Smaller deposits also are present between individual myofibrils and near two nuclei. (Case 7). $E M \times 12,000$.

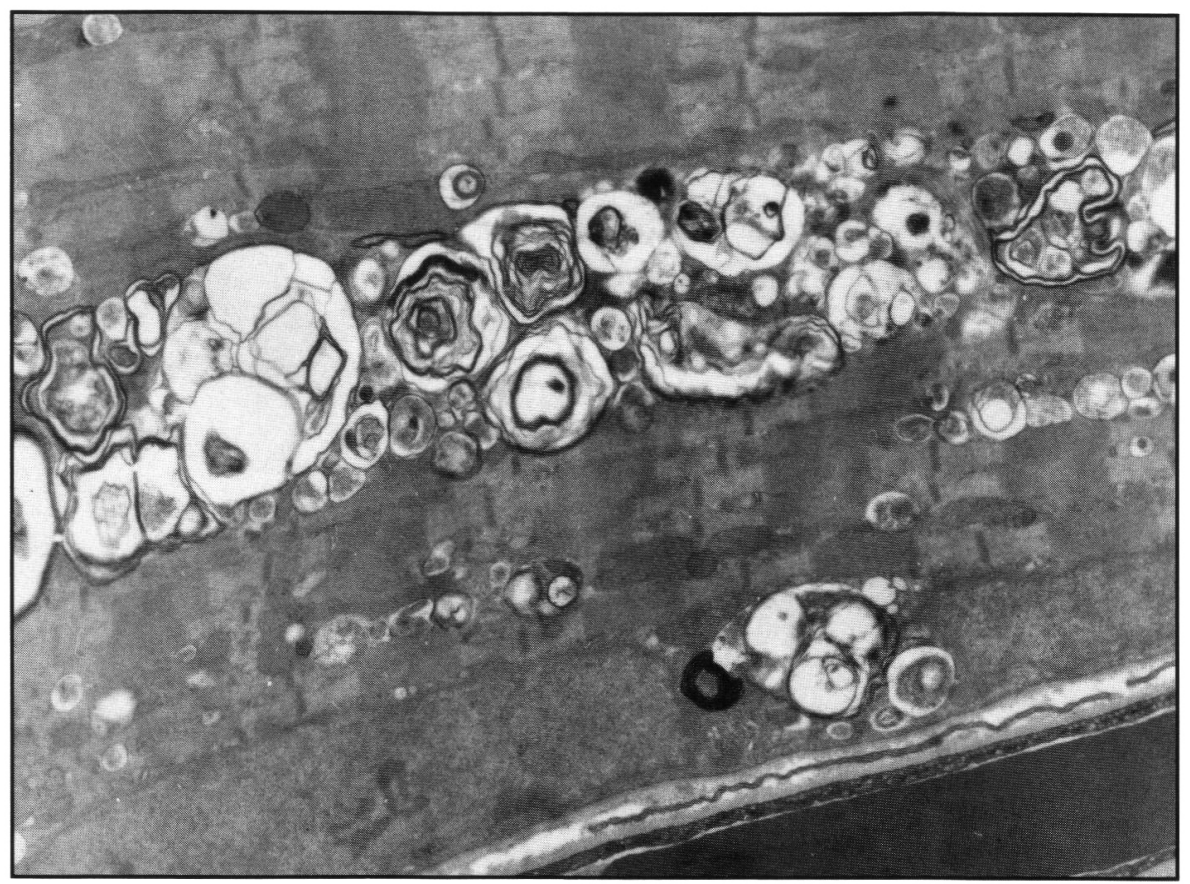


The exact nature and histogenesis of the nuclear filaments are still unknow. ${ }^{18-19}$ Their resemblance and differences with other intra/extranuclear filaments have been debated in a few papers. ${ }^{16,23,24}$ In immunocytochemical studies done by Tomé, et al ${ }^{19}$ all available antibodies directed against filaments did not mark the abnormal nuclei. EM studies also suggested that the filaments are not composed of DNA. 19

There is no other useful laboratory finding for diagnosis of OPMD. Furthermore, inclusions are present in asymptomatic muscles of patients with normal electromyographic findings and a normal creatine kinase (CK) level. In our group of patients, the CK level was found to be slightly to moderately elevated only in those with symptomatic proximal limb weakness. Abnormalities observed by light microscopy can be suggestive of OPMD, especially if there are mild myopathic changes with the presence of rimmed vacuoles, but these findings are not specific enough for confirmation of the diagnosis. A number of other histologic changes have been mentioned in a few cases of the oculopharyngeal "syndrome". Two recent papers 25,26 rekindled the old debate of neuronal degeneration which could be related to either severe denutrition or concomitant motor neuron disease. One of our cases did in fact have amyotrophic lateral sclerosis. In other reports, nonspecific mitochondrial abnormalities were shown in occasional fibres. ${ }^{27-29}$

Even though identification of the nuclear inclusions is fastidious, it is mandatory in the study of propositi from new families of OPMD, or sporadic unsettled cases of ptosis and dysphagia, because the clinical picture varies, and exact diagnosis is necessary for further genetic studies.

\section{REFERENCES}

1. Taylor EW. Progressive vagus-glossopharyngeal paralysis with ptosis: a contribution to the group of family diseases. J Nerv Ment Dis 1915; 42: 129-139.

2. Victor M, Hayes R, Adams RD. Oculopharyngeal muscular dystrophy; familial disease of late life characterized by dysphagia and progressive ptosis of the eyelids. N Engl J Med 1962; 267: 1267-1272.

3. Amyot R. Ptosis héréditaire familial et tardif des paupières supérieures. Un Méd Can 1948; 77: 1288-1294.

4. Saucier $J$. The clinical significance of ptosis with special reference to ptosis of late onset. J Nerv Ment Dis 1954; 119: 148-158.

5. Myrianthopoulos NC, Brown IA. A genetic study of progressive spinal muscular atrophy. Amer J Hum Genet 1954; 6: 387-4II.

6. Hayes R, London W, Seidman J, Embree L. Oculopharyngeal muscular dystrophy. New Engl J Med 1963; 268: 163.

7. Peterman AF, Lillington GA, Jampis RW. Progressive muscular dystrophy with ptosis and dysphagia. Arch Neurol 1964; 10: 38-41.

8. Bray GM, Kaarsoo M, Ross RT. Ocular myopathy with dysphagia. Neurology 1965; 15: 678 .

9. Barbeau A. Ocular myopathy in French Canada (abstract). Proceedings du 8 ième Congrès international de Neurologie, Vienne, 1965, tome II: 257-259.

10. Barbeau A. The Syndrome of Hereditary Late Onset Ptosis and Dysphagia in French Canada. In: Erich Kuhn, ed. Symposion über progressive Muskeldystrophie, Springer-Verlag 1966; 102109.

11. Letendre J, Tétreault C, Barbeau A. Dystrophie musculaire oculopharyngienne. Montréal Médical, janvier 1966: 11-13.

12. Russe $\mathbf{H}$, Busey $\mathrm{H}$, Barbeau A. Immunoglobulin changes in oculopharyngeal dystrophy. Proceedings of the Second International Congress of Neuro-Genetics and NeuroOphthalmology. Progress in Neuro-Genetics. Montréal 1967; Volume I: 62-65.

13. Tomé FMS, Fardeau M. Nuclear inclusions in oculopharyngeal dystrophy. Acta Neuropathol 1980; 49: 85-87.

14. Tomé FMS, Fardeau M. Ocular myopathies. Path Res Pract 1985; 180: 19-27.

15. Tomé FMS, Fardeau M. Ocular Myopathies. In: Myology, Engel AG and Banker BQ (editors). McGraw Hill, 1986; 1327-1345.

16. Tomé FMS, Fardeau M. Nuclear changes in muscle disorders. Meth Achiev Exp Pathol 1986; 12: 261-296.

17. Tomé FMS, Leroy JP, Neville $\mathrm{H}$ et al. Intranuclear tubulo-filamentous inclusions as morphological marker of oculopharyngeal muscular dystrophy. Muscle Nerve (Suppl) 1986; 9: 212 (Abstract)

18a. Tomé FMS, Askanas V, Engel WK, et al. Unusual nuclear inclusion in innervated culture muscle fibers of OPMD. Neurology (Suppl 1) 1988; 38: 340 (Abstract).

18b. Tomé FMS, Askanas V, Engel WK, Alverez MS, Lee C-S. Nuclear inclusions in innervated cultured muscle fibers from patients with oculopharyngeal muscular dystrophy. Neurology 1989; 39: 926-932.

19. Tomé FMS, Gounon P, Collin H, Ploton D, Shelanski ML, Fardeau M. Intranuclear inclusions in Oculopharyngeal muscular dystrophy: Further studies. Neurology (Suppl 1) 1989; 39: 335 (Abstract)

20. Dubowitz V, Brooke MH. Muscle biopsy: A modern approach WB Saunders Co London 1973; 231-241.

21. Jasmin G. (Personal communication to FMST).

22. Bouchard J-P, Brunet D, Gagné F, Puymirat J. La dystrophie oculopharyngée au Québec: Nouvel intérêt clinique, généalogique et morphologique. Can J Neurol Sci 1988; 15: 244 (Abstract).

23. Smith TW, Chad D. Intranuclear inclusions in oculopharyngeal dystrophy. Muscle Nerv 1984; 7: 339-340.

24. Coquet M, Vital C, Stoll D, Dominguez M, Julien J. Etude comparative des biopsies musculaires squelettiques et pharyngées de 3 cas d'atteinte oculopharyngeé. Résumés du 3ème Colloque national sur les Maladies Neuromuscularies, Bordeaux-Lac, $1988 ; 96$.

25. Schmitt HP, Krause KH. An autopsy study of a familial oculopharyngeal muscular dystrophy (OPMD) with distal spread and neurogenic involvement. Muscle Nerve 1981; 4: 296-305.

26. Probst A, Tackmann W, Stoeckli HR, Jerusalem F, Ulrich J. Evidence for a chronic axonal atrophy in oculopharyngeal "muscular dystrophy". Acta Neuropathol 1982; 57: 209-216.

27. Julien J, Vital $C$, Vallat JM, Vallat $M$, LeBlanc $M$. Oculopharyngeal muscular dystrophy. A case with abnormal mitochondria and "fingerprint" inclusions. J Neurol Sci 1974; 21: 165-169.

28. Pratt MF, Meyers PK. Oculopharyngeal muscular dystrophy: recent ultrastructural evidence for mitochondrial abnormalities. Laryngoscope 1986; 96: 368-373.

29. Dobrowski JM, Zajtchuk JT, Lapiana FG, Hensley SD. Oculopharyngeal muscular dystrophy: clinical and histopathologic correlations. Otolaryngol Head Neck Surg 1986; 95: 131142. 